\title{
The Role of the Government in Increasing Community Welfare in Pohuwato Regency
}

\author{
Edy Sijaya \\ Jurusan Ilmu Pemerintahan, Fakultas Ilmu Sosial dan Ilmu Politik \\ Universitas Ichsan Gorontalo \\ Email: edysijaya@gmail.com
}

(Received: March-2019; revised: April -2019; published: June -2019)

\begin{abstract}
This research aims to determine the role of the village government in improving the welfare of the people of Bulili Village in Duhiadaa District, Pohuwato Regency. The research approach uses descriptive research which provides an overview of how the government plays a role in improving the welfare of the community in the village of Bulili, Duhiadaa District, Pohuwato Regency. Informants were the village head, village head, BPD chairman, LPM Chair, village treasurer and Bulili village community leaders. The results showed that the Bulili Village Government in improving community welfare carried out three programs such as: 1) agricultural production improvement program. For the economic sector the Bulili village government planned assistance that would improve the economy of Bulili villagers such as providing rice seeds, corn seeds, tractor assistance, Hansplayer (tengki) assistance, fertilizer assistance, and PNPM assistance, 2) program to increase livestock production, namely the collaboration of district government, sub-district government and Bulili village government in the form of providing assistance for productive superior cows and productive goat seeds to village community livestock farmers bulili which was formed by the village village government. 3) development of village livestock agribusiness, which is to form a group of livestock farmers who are given the assistance of productive cow and goat seeds to each group to be managed as part of a government program in order to improve the welfare of the village community. In addition, the formation of livestock farmer groups is one of the right solutions in increasing livestock business in the village, various livestock businesses such as the procurement of productive seeds, prevention of livestock diseases and access to marketing can be done in groups and work together which in turn increases profits and business income in order to improve the welfare of the people in Bulili village.
\end{abstract}

Keywords: Government; Community Welfare; Welfare.

\section{INTRODUCTION}

Increasing people's welfare certainly requires a long process, and of course must understand and pay attention to the habits and way of life of these communities (Han \& Gao, 2019; Harrikari, 2014; Lwin, Fallon, Trocmé, Fluke, \& Mishna, 2018; Mersky, Topitzes, \& Blair, 2017). In improving the welfare of rural communities it must indeed be made aware of and taken into account by the village government, and also by the community itself so as to enable the growth of self-reliance or community participation in the process of implementation (Ang, 2019; Jaeger, Röjvik, \& Berglund, 2015; Salemink \& Strijker, 2018; Satyal, 2018)

Copyright (C) 2018 Universitas Negeri Makassar. This is an open access article under the CC BY license (http://creativecommons.org/licenses/by/4.0/) 


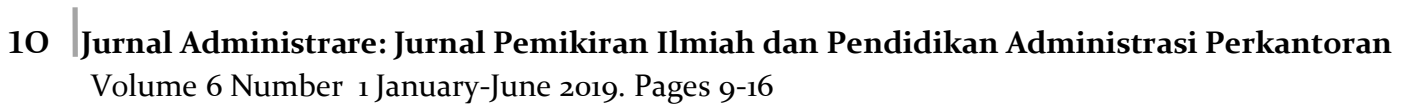

Regional autonomy has become a new hope for the government and village communities to build their villages according to the needs and aspirations of the community. for most village government officials, autonomy is a new opportunity that can open space for creativity for village officials in managing the village (Daraba, 2017; Daraba, Ramli, Sakawati, \& Salam, 2018; Nawir, Maulana, Nuryamin, \& Husain, n.d.; M. S. Saggaf, Akib, Salam, Baharuddin, \& Kasmita, 2018; M. S. Saggaf, Aras, et al., 2018; M. S. Saggaf \& Salam, 2017; S. Saggaf, Salam, Kahar, \& Akib, 2014; Salam, 2015; Salam \& Rosdiana, 2016; Salam, Rosdiana, Suarlin, \& Akib, 2014).

In order to achieve the goal of improving the welfare of rural communities more effectively, the village government and its community need to create a strategy to achieve these goals. In designing the strategy in question, the village government needs to pay attention to principles such as: 1) There is synergy between the village government and the village community, where the government knows about what is needed by the community, 2) Participatory, where the community is actively involved in the activities of the process planning, implementation, and utilization, and 3) alignments, where the orientation of activities both in the process and utilization of results to the entire village community.

The birth of Law Number 23 Year 2014 concerning Regional Government and Law Number 6 of 2014 concerning villages provides an opportunity for rural communities to regulate and manage their own households, with mandated requirements, which are carried out by taking into account the principles of democracy, community participation , equity, justice, and paying attention to the potential and diversity of society.

In practice, government roles and initiatives are still dominant in planning and implementation as well as to increase villagers' awareness and technical capabilities in developing village welfare. Various theories say that consciousness. the village head as the head of the village government or the actor in carrying out the leadership of the village government is the spearhead of the implementation and implementation of development and development of the welfare of the village community.

The effort to improve the welfare of the village community is a social condition of a country as it is known that the village community is a component and part of the Indonesian community. One of the main objectives of improving the welfare of rural communities is how to then improve the quality of a village. The existence of a village program that has not yet been carried out by the Bulili village government has made the writer consider that there are still shortcomings in improving the welfare of the community in Bulili village.

\section{METHOD}

This research was conducted in Bulili Village, Duhiadaa District, Pohuwato Regency, Gorontalo Province. The type of research used is descriptive, which provides an overview of how the government plays a role in improving the welfare of the community in the village of Bulili, Duhiadaa District, Pohuwato Regency. The technique of determining informants in this study was purposive sampling, so the informants who would be selected were people who were expected to have knowledge, experience, and competence on the problems to be studied. The informants in this study were 15 people consisting of: Bulili Village Chief, Village Secretary, 
Bulili Village Apparatus, Hamlet Heads, Bulili Village BPD Chair, Chairperson of LPM and Bulili village community leaders. As for some data collection techniques in this study, namely: 1) Interviews are data collection techniques by asking questions directly to the interviewer to the respondent and the respondent's answers are recorded or recorded. (Sugiyono 2007: 194), 2) Documentation is a data collection technique that is carried out by examining documents that are relevant to the research problem. With this technique data will be collected from the resource person but it is found in various written sources, such as government-issued documents, reports and other archives. Documentation is needed to obtain data that is relevant to research problems that are impossible to obtain by observation and interview, 3) Library study (library research), namely by reading books, documents, laws, and other information media related to the role of the government in Bulili Village, Duhiadaa District, Pohuwato Regency.

Data analysis is an activity of grouping, making a sequence, increasing data so that it is easy to make a description. In accordance with the research method, the data analysis technique used in this study uses qualitative techniques. According to Farid (1997: 152) that qualitative analysis is an analysis of the data obtained based on the reasoning ability of researchers in connecting facts, data and information.

\section{RESULT AND DISCUSSION}

In the process of improving the welfare of rural communities, the role of the government in this case the village government is very important because the village government is the government that is closest to the community. That's why the allocation of village funds (ADD) as a development budget sourced from the APBD can be managed optimally. Bulili Village has diverse resource potential in developing village potential, both physical, social, population and cultural resources. The Bulili Village Government in improving community welfare carried out three programs such as: 1) programs to increase agricultural production, 2) programs to increase livestock production, and 3) development of village livestock agribusiness.

\section{Agricultural Production Improvement Program}

In the 2016-2021 village mid-term Development Plan (RPJM-des) in Bulili village, the village government drafted activities in developing villages, both in the fields of infrastructure, education, the health sector, the agricultural sector, and livestock, human resources and youth sectors. the SMEs sector, as well as the security sector. For the agriculture sector itself there are several activities planned to increase agricultural production. Based on the results of interviews with researchers with the Bulili Village Head regarding the efforts made by the village government to improve the welfare of the villagers in Bulili, I say that:

"The efforts made by the village government in improving the welfare of the community in Bulili village are 2 programs, namely: 1) The economic sector, 2) The area of development of the region. For the economic sector, the Bulili village government plans to provide assistance that will improve the economy of Bulili villagers, such as providing rice seeds, corn seeds, tractor assistance, and PNPM assistance. (Results of interview October 22, 2018). 


\section{Jurnal Administrare: Jurnal Pemikiran Ilmiah dan Pendidikan Administrasi Perkantoran \\ Volume 6 Number 1 January-June 2019. Pages 9-16}

Whereas things related to the program carried out by the village government in increasing agricultural and plantation production in Bulili village, based on the results of interviews with researchers with the Head of Government Affairs stated that:

"The superior commodity bullies are agriculture", so the government program in increasing agricultural and plantation production is by providing agricultural seeds. The assistance provided by the village government in improving the welfare of agricultural production includes: Providing assistance with corn seeds, hansplayer assistance (tengki), grass trimmer assistance, fertilizer assistance, agricultural extension services, and irrigation development. (Results of interview October 22, 2018)

To improve the welfare of the community through increasing agricultural production various efforts have been made by the government, many farmers still complain about the lack of socialization and agricultural extension in Bulili villages so that many farmers only do it in a traditional way and according to what they understand. In connection with this matter the researcher asked this matter to the General Head, namely Ms. Yusna Mahmud he revealed that:

"The government must hold a lot of information on agriculture / plantations so that the farmers are very well motivated. Because now the local government through the agricultural office is still lacking in socialization in this village so that many farmers still do not understand and have not been motivated to increase their agricultural production. (Results of interview October 22, 2018).

Another thing that was conveyed by Thalib Tantu as a community leader who was also one of Bulili village farmers said:

"So far the local government is still not proactive in carrying out and carrying out socialization on agriculture which has become an official duty of agriculture, as well as the village government and related officials, in fact the village government has not been able to carry out tasks in each field. (Results of interview October 23, 2018).

Based on the interview quotations from several informants above, it can be concluded that in order to increase the people's welfare through increasing agricultural production, Bulili village government has made various efforts, among others, by focusing on two programs, namely the economy and regional development, in the economic sector, the village government has sought provide assistance for rice seeds, corn seeds, tractor assistance, and PNPM assistance and so on. The superior commodity bullies are agriculture ", so government programs to increase agricultural and plantation production are carried out by providing agricultural seeds. However, these efforts are not directly proportional to the ability and motivation of farmers in managing the most superior commodities in the village Bulili, because it is caused by the lack of socialization carried out by the local government through the agricultural service, causing farmers to still be less than optimal in increasing agricultural production.

\section{Program to Increase Animal Husbandry Production}

In the list of priority activities for the duhiadaa sub-district in 2018, the sub-district government explained to the farm itself, namely the assistance program for superior cows and goats, besides that there was also a program to develop and develop fisheries in this case a freshwater pond. For the Bulili village program itself in the field of animal husbandry there are several programs, namely: 1) procuring productive female cattle, 2) procuring goat and poultry 
livestock breeds. This was confirmed by one of the informants, the treasurer of the Bulili village who said that:

"Program programs carried out by Bulili village government are to improve the standard of living of the community, therefore the village government provides assistance to the community through farmer groups that have been formed by the village government based on the results of verification to the community who are engaged in the midwife farm. (Results of interview October 23, 2018).

While according to the village community leaders Bulili he said:

"Same as said by the treasurer that the villagers in the village always receive assistance from the government but in reality the assistance is not given to the people in need, but only those who are close to the village officials who get the assistance. (Results of interview October 23, 2018).

Quotations of interviews illustrate that the efforts made by Bulili village government in improving community welfare are by the cooperation of local governments, sub-district governments and village governments through a program of assistance for productive superior cows and productive goat seeds. However, from interviews and findings of researchers in the field that the government assistance program to the community has not been right on target or has not directly touched the people who really need the assistance, the researchers found that village government assistance is usually only given to people certain because of the emotional closeness that the program is still complained of by some villagers in Bulili.

\section{Village Livestock Agribusiness Development}

The challenge of future livestock development is the ability to provide domestic food support (local, regional, and national) to provide great support for the industry and make the most of comparative advantage so that the industry has competitiveness in the global market. because the future livestock industry must also have a high understanding of social change, including climate change, increasing profits and benefits for livestock entrepreneurs and guaranteeing proper food production, practically future farms must have resilience based on knowledge and technology.

Based on the results of interviews with Bulili village heads, it was said that:

"In relation to the development of the livestock sub-sector, the Bulili village government takes a strategic step in empowering farmer farmers by providing understanding both through counseling and communication between farmers so that they can improve their livestock business. One of the efforts taken by the village government is to involve farmer farmers in making decisions regarding government programs that will be implemented regarding the issue of increasing rural livestock agribusiness. In addition, the efforts of the village government in the form of controlling livestock diseases include maintaining health and preventing transmission of diseases between livestock and humans, including healthy and safe production of livestock food and healthy and safe control of livestock 


\section{Jurnal Administrare: Jurnal Pemikiran Ilmiah dan Pendidikan Administrasi Perkantoran Volume 6 Number 1 January-June 2019. Pages 9-16}

diseases, controlling livestock diseases in the future because this is a very important issue in the trade in livestock products. (Results of interview October 23, 2018).

When the writer conducted an interview with the head of the Popaseda hamlet it was said that:

"The efforts made by the Bulili village government in empowering livestock farmers are by forming a livestock farmer group, which will be given assistance to productive cows and productive goat seeds to each group". (Results of interview October 23, 2018).

Based on the results of the interviews above, it can be concluded that the efforts of the Bulili village government in Duhiadaa sub-district of Pohuwato Regency in relation to the development of village livestock agribusiness are to form a group of livestock farmers who are given productive cow and goat seedlings to each group to be managed as part of government programs in order to improve welfare villagers. In addition, the formation of livestock farmer groups is one of the right solutions in increasing livestock business in the village, various livestock businesses such as the procurement of productive seeds, prevention of livestock diseases and access to marketing can be done in groups and work together which in turn increases profits and business income in order to improve the welfare of the people in Bulili village.

\section{CONCLUSION}

The efforts made by the village government in improving the welfare of the community through three programs such as: 1) increase in agricultural production. For the economic sector, the village government of Bulili planned assistance that would improve the economy of Bulili villagers such as providing rice seeds, corn seeds, tractor assistance, hansplayer assistance. (tengki), fertilizer assistance, and PNPM assistance. 2) a program to increase livestock production, namely the collaboration of the district government, sub-district government and Bulili village government in the form of providing assistance for productive superior cows and productive goat seeds to the Bulili community farmer groups formed by the village government of Bulili. And 3) the development of village livestock agribusiness, which is to form a group of livestock farmers who are given the assistance of productive cow and goat seeds to each group to be managed as part of a government program to improve the welfare of the village community. In addition, the formation of livestock farmer groups is one of the right solutions in increasing livestock business in the village, various livestock businesses such as the procurement of productive seeds, prevention of livestock diseases and access to marketing can be done in groups and work together which in turn increases profits and business income in order to improve the welfare of the people in Bulili village.

\section{REFERENCES}

Ang, S. (2019). Life course social connectedness: Age-cohort trends in social participation. Advances in Life Course Research, 39, 13-22. https://doi.org/https://doi.org/10.1016/j.alcr.2019.02.002 
Daraba, D. (2017). Pengaruh Program Dana Desa terhadap Tingkat Partisipasi Masyarakat di Kecamatan Galesong Utara Kabupaten Takalar. Sosiohumaniora, 19(1).

Daraba, D., Ramli, R. M., Sakawati, H., \& Salam, R. (2018). Quality Of Service Manufacturing Of Trade License Line In Office Of Investment Investment And Licensed Agency (BPMPT) Regency Of Bulukumba. THE INTERNATIONAL CONFERENCE ON SOCIAL SCIENCES AND HUMANITIES 2018, 485-490.

Han, H., \& Gao, Q. (2019). Community-based welfare targeting and political elite capture: Evidence from rural China. World Development, 115, 145-159. https://doi.org/https://doi.org/10.1016/j.worlddev.2018.11.010

Harrikari, T. (2014). Social disorganization and the profile of child welfare: Explaining child welfare activity by the community-level factors. Child Abuse \& Neglect, 38(10), 16711682. https://doi.org/https://doi.org/10.1016/j.chiabu.2014.07.005

Jaeger, G., Röjvik, A., \& Berglund, B. (2015). Participation in society for people with a rare diagnosis. Disability and Health Journal, 8(1), 44-50. https://doi.org/https://doi.org/10.1016/j.dhjo.2014.07.004

Lwin, K., Fallon, B., Trocmé, N., Fluke, J., \& Mishna, F. (2018). A changing child welfare workforce: What worker characteristics are valued in child welfare? Child Abuse \& Neglect, 81, 170-180. https://doi.org/https://doi.org/10.1016/j.chiabu.2018.04.029

Mersky, J. P., Topitzes, J., \& Blair, K. (2017). Translating evidence-based treatments into child welfare services through community-university partnerships: A case example of parentchild interaction therapy. Children and Youth Services Review, 82, 427-433. https://doi.org/https://doi.org/10.1016/j.childyouth.2017.10.002

Nawir, R., Maulana, R., Nuryamin, M., \& Husain, T. (n.d.). Implementation Program of Poor Rice Copyright.

Saggaf, M. S., Akib, H., Salam, R., Baharuddin, A., \& Kasmita, M. (2018). The Quality Analysis Of Academic Services.

Saggaf, M. S., Aras, M., Akib, H., Salam, R., Baharuddin, A., \& Kasmita, M. (2018). The Quality Analysis of Academic Services Based on Importance Performance Analysis (IPA).

Saggaf, M. S., \& Salam, R. (2017). Examining Academic Service using Importance Performance Analysis (IPA).

Saggaf, S., Salam, R., Kahar, F., \& Akib, H. (2014). Pelayanan Fungsi Administrasi Perkantoran Modern. Jurnal Ad'ministrare, 1(1), 20-27.

Salam, R. (2015). Penerapan Fungsi Administrasi Perkantoran Modern berbasis Daya Saing Organisasi dalam menyongsong MEA 2015. SEMINAR NASIONAL "Revolusi Mental Dan Kemandirian Bangsa Melalui Pendidikan Ilmu-Ilmu Sosial Dalam Menghadapi MEA 2015” Himpunan Sarjana Pendidikan Ilmu-Ilmu Sosial Indonesia, 1, 186-190.

Salam, R., \& Rosdiana. (2016). Penerapan Fungsi Administrasi Perkantoran Modern Berbasis Daya Saing Organisasi dalam Menyongsong MEA 2015. SEMINAR NASIONAL "Revolusi Mental Dan Kemandirian Bangsa Melalui Pendidikan Ilmu-Ilmu Sosial Dalam Menghadapi MEA 2015" Himpunan Sarjana Pendidikan Ilmu-Ilmu Sosial Indonesia, 1(2016), 186-190. Fakultas Ilmu Sosial Universitas Negeri Makassar.

Salam, R., Rosdiana, Suarlin, \& Akib, H. (2014). The Impact Of Policy on Region Expansion to Office Administrative Services in Barombong Subdistrict of Gowa District. International Conference on Mathematics, Sciences, Technology, Education and Their Applications, 1(1), 505. State University of Makassar. 
16 Jurnal Administrare: Jurnal Pemikiran Ilmiah dan Pendidikan Administrasi Perkantoran Volume 6 Number 1 January-June 2019. Pages 9-16

Salemink, K., \& Strijker, D. (2018). The participation society and its inability to correct the failure of market players to deliver adequate service levels in rural areas. Telecommunications Policy, 42(9), 757-765. https://doi.org/https://doi.org/10.1016/j.telpol.2018.03.013

Satyal, P. (2018). Civil society participation in REDD+ and FLEGT processes: Case study analysis from Cameroon, Ghana, Liberia and the Republic of Congo. Forest Policy and Economics, 97, 83-96. https://doi.org/https://doi.org/10.1016/j.forpol.2018.09.012 